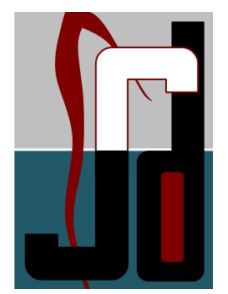

\title{
REVIEW
}

\section{Biomarkers -A Diagnostic Tool for Periodontal Diseases}

\author{
Anitha.K ${ }^{1}$, Pratebha Balu ${ }^{2}$,Sakthi Devi.S ${ }^{3}$,Arun Kumar. $A^{4}$
}

ABSTRACT: The conventional clinical diagnostic aids which were introduced almost half a century ago continues to function as the basis of diagnosis in clinical practice. Recent advances in biochemistry and molecular sciences brought us to the significance of biomarkers as diagnostic aids. This new advance in medical science for periodontal diagnosis will provide immense benefit in managing periodontitis patients. Biomarkers are tell - tale molecules that can be used to monitor health status, disease onset, treatment response and outcome.

These biomarkers can be obtained from various body fluids. Obtaining GCF by non invasive method provides an easy and reliable modality in using GCF as potential source for biomarkers

This simple and non- invasive nature of GCF sourcing and its high sensitivity assay development have led to the idea of using the GCF biomarkers as diagnostic aids for periodontal diagnosis.

Keywords: biomarkers, gingival crevicular fluid, periodontitis

Periodontitis is a chronic inflammatory disease of bacterial origin causes progressive destruction of the periodontium that supports the teeth ${ }^{[1]}$ Studies of the host immune response to pathogenic bacteria have contributed to the current understanding of the pathogenesis of periodontal diseases ${ }^{[2]}$. The traditional methods by which clinicians diagnose periodontal disease have remained virtually unchanged. The conventional diagnosis of periodontal disease relies almost exclusively on clinical parameters such as probing depth (PD) and clinical attachment level (CAL) and traditional dental radiography. The strengths of these traditional tools are their ease of use, their costeffectiveness, and that they are relatively noninvasive. But these diagnostic procedures are inherently limited, in that only disease history, not current disease status, can be assessed. So, there is a need for the development of new diagnostic tests that can detect the presence of active disease, predict future disease progression, and evaluate the response to periodontal therapy, thereby improving the clinical management of periodontal patients. This article highlights recent advances in the use of biomarker-based disease diagnostics that focus on the identification of active periodontal disease from gingival crevicular fluid (GCF) ${ }^{[3]}$

Biomarkers are "A characteristic that can be measured and evaluated as an indicator of normal biological processes, pathological processes or pharmacologic responses to therapeutic Journal of Scientific Dentistry, 3(1), 2013 
interventions" (NIH Biomarkers

Definitions Working Group, 1998)

\section{Classification of Biomarkers from GCF}

Biomarkers that are released into GCF can be broadly grouped according to their sources ${ }^{[3]}$

1. Inflammatory Mediators: Cytokines, Interleukins, Tumor necrosis factor- $\alpha$, Interferon- $\alpha$, Prostaglandin E2, matrix metalloprotinase, transferrin, C-reactive protein

2. Host Derived: Aspartate Aminotransferase, Elastase, Cathepsin $\mathrm{G}, \mathrm{b}-$ glucuronidase, Alkaline phosphatase, Acid phosphatase, Myeloperoxidase

3. Lysozyme Connective Tissue Breakdown Products: Collagen-telopeptides,

Osteocalcin, Proteoglycans, Breakdown products, Fibronectin fragments.

\section{Host Response and Inflammatory}

\section{Mediators as Potential Biomarkers}

Periodontal inflammation occurs in the gingival tissue in response to bacterial biofilm. Gingivitis is characterized by an initial increase in the blood flow, enhanced vascular permeability and the influx of inflammatory cells (neutrophils and monocytes-macrophages) from the peripheral blood to the gingival crevice. Subsequently $\mathrm{T}$ cells and B cells appear at the infection site and these cells produce a myriad of cytokines.

Cytokines: The majority of cytokines have been renamed as interleukins referring to their role in communication between leukocytes. The cytokines, prostaglandin E2, TNF- $\alpha$, MMPs play major role in the pathogenesis of periodontal diseases. Bacteria induce tissue destruction indirectly by activating host defence cells, which in turn produce and release mediators that stimulate the effectors of connective tissue break down. These mediate the inflammatory process and acts as markers of inflammation [4].

\section{Tumour Necrosis Factor (TNF):}

Components of microbial plaque have the capacity to induce the initial infiltrate of inflammatory cells including PNMs, lymphocytes and macrophages. Microbial components, especially lipopolysaccharide (LPS), have the capacity to activate macrophages to synthesize and secrete a wide array of molecules including the interleukin-1 (IL-1) and tumor-necrosis factor-alpha (TNFalpha), prostaglandins, especially PGE2, and hydrolytic enzymes. These cytokines manifest 
potent proinflammatory and catabolic activities, and play key roles in periodontal tissue breakdown. Elevated levels of tumor necrosis factor- $\alpha \quad(\mathrm{TNF}-\alpha)$ or interleukin 6 (IL-6 and adipokines are known risk factors for destructive periodontal disease ${ }^{[5]}$.

Matrix Metalloproteinases: MMPs are a family of proteolytic enzymes that mediate the degradation of extracellular matrix molecules, including interstitial and basement membrane collagens, fibronectin, laminin, and proteoglycan core protein ${ }^{[6]}$. The enzymes are secreted or released in latent form and become activated in the pericellular environment by disruption of a $\mathrm{Zn}+$. Cytokines like IL $-1, \mathrm{TNF} \alpha$ and $\mathrm{TGF} \alpha$ regulate expression of MMP genes in periodontal tissue. Matrix metalloproteinase (MMP) -8, collagenase-2, is a key mediator of irreversible tissue destruction in chronic periodontitis and detectable in gingival crevicular fluid (GCF) ${ }^{[7]}$

Prostaglandins: Bacteria induce tissue destruction indirectly by activating host defence cells, which in turn produce and release mediators that stimulate the effectors of connective tissue break down including prostaglandin E2. These mediate the inflammatory process and acts as markers of inflammation. prostaglandin E2 seen three times more in inflammed tissues than in normal tissues [2].

\section{Hydrolytic Enzymes Of Tissue Origin}

The inflammatory cells contain destructive enzymes within their lysosomes which are normally used to degrade phagocytosed material. These enzymes are however capable of degrading gingival tissue components if released. Such enzymes may be released by inflammatory cells during their function or when they degenerate or die. The main enzymes released by these cells are listed below.

Cysteine proteinases: Cathepsins B, L and $\mathrm{H}$ are a family of intracellular cysteine proteinases which can degrade extracellular components including collagen. They act at acid $\mathrm{pH}$ and are primarily involved in intracellular degradation but are also active extracelluarly when released during inflammation $^{[8]}$

\section{Serine Proteinases}

Elastase-Elastase in gingival tissue in produced by neutrophil poly morpho 
nuclear leucocytes (PMNs) and it is held within the cell in an inactive form probably bound with an inhibitor. Elastase is able to degrade proteoglycans and can also activate latent collagenase. Elastase is present in both saliva and GCF and can be biochemically assayed from these sources. GCF elastase levels significantly correlate with increasing gingival inflammation, probing depth, probing attachment level and bone loss and its level also significantly reduces following periodontal treatment ${ }^{[9]}$

Tryptase-Tryptase activity is present in large amounts in gingival tissue and in small amounts in GCF when measured biochemically and it has been localized to gingival mast cells. In the mast cell granules its stabilized as an active tetramer by association with heparin and is released by these cells on degranulation. Tryptase can cleave the third component of complement and can activate latent collagenase ${ }^{[9]}$.

A l k a li n e phosphat a s e - A $1 \mathrm{ka} 1 \mathrm{ine}$ phosphatase is thought to play a role in bone metabolism and is found in PMNs. A cross-sectional study of GCF alkaline phosphatase in periodontitis patients showed that it positively and significantly correlated with pocket depth but not with bone loss and is found at higher levels at diseased than healthy sites ${ }^{[10]}$

Acid phosphatase-Acid phosphate is present in inflammatory cells and has been detected in GCF). Levels however do not correlate with measurements of either disease severity or activity.

Myeloperoxidase- Myeloperoxidase (MPO) is a potent antibacterial enzyme produced by PMNs. Salivary MPO levels are significantly higher in untreated chronic periodontitis patients compared with healthy control subjects and their levels significantly reduce following periodontal treatment GCF MPO levels are higher a periodontitis sites than control sites and the levels decrease significantly following periodontal treatment ${ }^{[11]}$

Lysozyme-Lysozyme (muraminidase) is an antibacterial enzyme found in body secretions, notably tears and saliva. It is also found in GCF. Salivary Lysozyme levels have been reported to be significantly lower in chronic periodontitis and insulin-dependent diabetes mellitus patients than healthy 
control subjects.

Lactofer rin-Lactoferrin is a n antibacterial agent produced by inflammatory cells. The levels of salivary and GCF lactoferrin are significantly increased in untreated LJP patients compared with healthy controls and decreased to normal levels following periodontal treatment

\section{Aspartate amino transferase (AST)}

Lactate dehydrogenase (LDH).)-They are soluble cytoplasmic enzymes which are confined to the cell cytoplasm but are released by dead or dying cells. Since cell death is an integral and essential component of periodontal tissue destruction they should be released during this process and should pass with the inflammatory exudates into GCF [12].

Markers of connective tissue degradation

During its passage through the inflamed tissue, GCF could pick up normal components of the extracellular matrix or tissue-degradation products released during the destructive process. The components that could be involved in this process are listed below.

Commercially Available Chairside Diagnostic Kits

\begin{tabular}{|c|c|c|c|}
\hline ASSAY & KIT & MANUFACTURER/SUPPLIER & FUNCTION \\
\hline \multirow{3}{*}{$\begin{array}{c}\text { Bacterial enzymes } \\
\& \\
\text { host enzymes }\end{array}$} & $\begin{array}{l}\text { BANA periodon- } \\
\text { tal test }\end{array}$ & Ora Tec Corporation Manassas (USA) & $\begin{array}{l}\text { It utilizes the BANA test for } \\
\text { bacterial trypsin like proteases. }\end{array}$ \\
\hline & $\begin{array}{c}\text { Periocheck } \\
\text { (ASTech) }\end{array}$ & $\begin{array}{c}\text { CollaGenex Pharmaceuticals, Newtown, } \\
\text { PA }\end{array}$ & $\begin{array}{l}\text { Detects presence of neutral } \\
\text { proteinases i.e. Collagenase }\end{array}$ \\
\hline & PerioScan & Oral B Laboratories & $\begin{array}{c}\text { Detects enzymatic activity } \\
\text { of Aggregatibacter actinomy- } \\
\text { cetemcomitans, T forsythus, } P \\
\text { gingivalis }\end{array}$ \\
\hline $\begin{array}{c}\text { Immunological } \\
\text { detection }\end{array}$ & Evalusite & Kodak Eastman Company (Switzerland) & $\begin{array}{l}\text { Immunological detection of } \\
\text { antigens of } \text { Aggregatibacter } \\
\text { actinomycetemcomitans, } P \\
\text { intermedia, } P \text { gingivalisusing } \\
\text { antibodies (ELISA) }\end{array}$ \\
\hline \multirow[t]{5}{*}{$\begin{array}{l}\text { Biochemical } \\
\text { Identification }\end{array}$} & Prognostic & Dentsply & $\begin{array}{c}\text { Aids in detection of serine } \\
\text { proteinases and elastases }\end{array}$ \\
\hline & Biolise & $\begin{array}{l}\text { SLT-Labinstruments, Crailsheim, Ger- } \\
\text { many }\end{array}$ & Aids in detection of elastase \\
\hline & Periogard & Colgate & Detects the presence of AST \\
\hline & Pocket watch & SteriOss ${ }^{\circledR}$, San Diego, CA, USA & $\begin{array}{l}\text { Detects aspartate aminotrans- } \\
\text { ferase through colorimetric } \\
\text { detection }\end{array}$ \\
\hline & TOPAS & Affinity Labelling Technologies (USA) & $\begin{array}{l}\text { Detects toxins derived from } \\
\text { anaerobic metabolism and } \\
\text { measures GCF protein level }\end{array}$ \\
\hline
\end{tabular}


Fibronectin- Is a normal component of serum and the connective tissue matrix, is present in GCF and more intact molecules are present in samples from healthy and treated sites than from diseased sites $^{[13]}$

Glycosaminoglycans-The extracellular ground substance of connective tissues contains a series of hexauronatecontaining hetero poly-saccharides termed glycos-amino-glycnas (GAGs) which are linked to a specific core protein to form high-molecular-weight aggregates called proteoglycan.

\section{CONCLUSION}

Diagnostic tests are routinely used in evaluation of many systemic disorders. where as,diagnosis of periodontal disease relies primarily on clinical and radiographic evidences. These measures are predominantly useful in detecting history of past diseases, or verifying periodontal health, rather than providing sufficient information about patients and sites at risk for future periodontal disease. This short review of the literature concerning the use of GCF for periodontal diagnosis allows some conclusions to be drawn regarding the types of biochemical agents that appear in GCF holds promise as useful tests for periodontal disease. Longer and wider studies examining the relationship of the identified biomarkers to the natural history of periodontal disease is the obvious next step in this line of investigation. It could be used to monitor the general periodontal health and the onset of specific diseases. Biomarkers, whether produced by normal healthy individuals or by individuals affected by specific periodontal diseases, are tell-tale molecules that could be used to monitor health status, disease onset, treatment response and outcome. Informative biomarkers can further serve as early signs of disease, and this has been considered as the most promising alternative to conventional tools in periodontics .

\section{REFRENCES}

1. Albandar JM, Brunelle JA, Kingman A. Destructive periodontal disease in adults 30 years of age and older in the United States, 1988-1994. J Periodontol 1999; 70:13-29

2. Offenbacher, B.M.Odle, R.C.Gray, T.E.Van Dyke Crevicular fluid prostaglandin E levels as a measure of the periodontal disease status of adult and juvenile periodontitis patients .Journal of periodontal research 1984:19; 1-13

3. Taba M, Kinney J, Kim AS et al. Diagnostic Biomarkers for Oral and Periodontal Diseases. Dent Clin North America. 2005 July; 49(3): 551

4. Offenbacher S, Barros S, Mendoza L, et al. Changes in gingival crevicular fluid inflammatory mediator levels during the induction and resolution of experimental gingivitis in humans. J Clin Periodontol 2010;37:324-33 
5. Page RC R oozbeh Khosravi, Khady Ka, Ting Huang, Saeed Khalili, Bich Hong Nguyen, Belinda Nicolau, and Simon D. Tran 142 Tumor Necrosis Factor- $\alpha$ and Interleukin-6: Potential Interorgan Inflammatory Mediators Contributing to Destructive Periodontal Disease in Obesity or Metabolic Syndrome J Periodontal Res. 1991 May;26(3 Pt 2):230

6. Christgau, M.Moder, D.Hiller, K.A.Dada,A .Schmitz,G.Schmalz.Grow factors and cytokines in autologous platelet concentrate and their correlation to periodontal regeneration outcomes .Journal of clinical Periodontology 2006;33:837-845.

7. Paivi Mantyla The scientific basis and development of a matrix metalloproteinas(MMP)-8 specific chair-side test for monitoring of periodontal health and disease from gingival crevicular fluid..Academic dissertation for the degree of PhD .To be publicly discussed by the permission of the Faculty of Medicine, University of Hel- sinki

8. Eley.B.M And J.D.Manson -Periodontics. $5^{\text {th }}$ ed:Saunders \&Elsiever; 2004;55-82

9. Ira .B.Lamster and John .T.Grbic. Diagnosis of periodontal disease based on analysis of the host response.Periodontology 2000; 1995:83-95

10. Bartold.P.M ,A.Sampath Narayanan-Biology Of Periodontal Tissues. $1^{\text {st }}$ ed: Chicago; Quintessence Publication;1998;64-79

11. Cao.C.F. And Smith.Q.T Crevicular fluid Myeloperoxidase at healthy,gingivitis and periodontitis sites. Journal of clinical Periodontology 1989; $16: 17-20$

12. Chambers DA, Imrey PB, Cohen.R.L., Crawford .J.M. Alves M.E.A.F,Mcswiggin .T.A. A longitudinal study of aspartate aminotransferase in human gingival crevicular fluid.Journal of periodontal research 1991;26:65-74

13. Micheal G.Newman, Henry H.Takei,Fermin A.Carranza Carranza's Clinical Perioodntology 10thed.Missouri:Saunders Publication;2006;233
Address for correspondence:

Dr. K.Anitha

Reader,

Dept Of Periodontics

IndraGandhi Institute of Dental Sciences, Sri Bajai Vidapeeth University,Puducherry anitharameshbabu@rediffmail.com

\section{Authors:}

${ }^{1,2}$ Reader, ${ }^{3,4}$ Senior lecturer

Dept Of Periodontics

IndraGandhi Institute of Dental Sciences,

Sri Bajai Vidapeeth University

Puducherry

\section{How to cite this article:}

Anitha.K, Pratebha Balu,Sakthi Devi.S,Arun Kumar. Biomarkers -A Diagnostic Tool for Periodontal Diseases Jour nal of Scientific Dentistry 2013;3(1):59-65

Source of Support: Nil, Conflict of Interest: None declared 